\title{
Effects of exercises on pain and functional capacity in hospitalized cancer patients
}

\author{
Efeitos dos exercícios sobre a dor e a capacidade funcional em pacientes oncológicos \\ hospitalizados
}

Cláudia Ranzi ${ }^{1}$, Bibiana Ferrari Barrosoํ, Douglas Roberto Pegoraro', Amanda Sachetti², Carla Wouters Franco Rockenbach ${ }^{3}$, Leonardo Calegari ${ }^{3}$

\section{ABSTRACT}

BACKGROUND AND OBJECTIVES: There are few studies evaluating the effects of physiotherapy with multidimensional instruments on cancer pain. The objective of this study was to evaluate the effects of physiotherapy on pain and functional capacity in hospitalized cancer patients.

METHODS: This is a quasi-experimental study including 40 participants with a mean age of $51 \pm 18$ years assessed before and after physiotherapy interventions, using the verbal numerical rating scale, the McGill Pain Questionnaire - Short Form, the International Physical Activity Questionnaire, the Sit-to-Stand test, and the Eastern Cooperative Oncology Group questionnaire for functional capacity evaluation. The participants were classified according to the number of performed sessions: group $1 \leq 5$ sessions $(n=25)$ and group $2 \geq 6$ sessions $(n=15)$.

RESULTS: There was a reduction in cancer pain measured by sensory $(p=0.02)$ and mixed descriptors $(p=0.05)$ of the McGill questionnaire as well as by the numerical visual scale $(\mathrm{p}=0.03)$ in patients who performed at least six physiotherapy sessions. There was a significant correlation $(\mathrm{r}=0.81 ; \mathrm{p}<0.001)$ between the reduction in pain measured by the numerical visual scale and the reduction in pain measured by the Total McGill questionnaire.

Cláudia Ranzi - (1)https://orcid.org/0000-0003-4900-665X;

Carla Wouters Franco Rockenbach - Dhttps://orcid.org/0000-0002-2825-4673;

Leonardo Calegari - (1) https://orcid.org/0000-0003-0758-3467;

Amanda Sachetti - Dhttps://orcid.org/0000-0001-9991-0001;

Bibiana Ferrari Barroso - (Dhttps://orcid.org/0000-0001-5080-7089;

Douglas Roberto Pegoraro - Dhttps://orcid.org/0000-0002-6182-7330.

1. Universidade de Passo Fundo, Hospital São Vicente de Paulo, Residência Multiprofissional em Atenção ao Câncer, Passo Fundo, RS, Brasil.

2. Instituto Meridional de Educação, Escola de Saúde, Passo Fundo, RS, Brasil

3. Universidade de Passo Fundo, Faculdade de Educaçấo Física e Fisioterapia, Passo Fundo, RS, Brasil.

Submitted on December 09, 2018.

Accepted for publication on July 02, 2019.

Conflict of interests: none - Sponsoring sources: none.

Correspondence to:

Av. Brasil Leste, 285 - Sẫo José

99052-900 Passo Fundo, RS, Brasil.

E-mail: claudia.ranzi@hotmail.com

(C) Sociedade Brasileira para o Estudo da Dor
There were no significant differences in the Sit-to-Stand test and the Eastern Cooperative Oncology Group functional capacity questionnaire.

CONCLUSION: At least six sessions of physiotherapy with emphasis on kinesiotherapy were needed to promote a reduction of cancer pain in hospitalized patients. We recommend the use of multidimensional instruments in the evaluation of cancer pain in hospitalized patients submitted to physiotherapy.

Keywords: Cancer pain, Neoplasm, Pain measurement, Physiotherapy.

\section{RESUMO}

JUSTIFICATIVA E OBJETIVOS: São escassos os estudos que avaliaram os efeitos da fisioterapia sobre a dor oncológica com instrumentos multidimensionais. $\mathrm{O}$ objetivo deste estudo foi avaliar os efeitos da fisioterapia sobre a dor e a capacidade funcional em pacientes oncológicos hospitalizados.

MÉTODOS: Estudo quase-experimental, composto por 40 participantes com idade média de $51 \pm 18$ anos, avaliados pré e pós intervenção fisioterapêutica pela escala verbal numérica, Questionário de Dor de McGill, Questionário Internacional de Atividade Física, teste de sentar e levantar da cadeira e capacidade funcional pelo questionário Eastern Cooperative Oncology Group. Os participantes foram estratificados de acordo com o número de sessóes realizadas em grupo $1 \leq 5$ atendimentos $(n=25)$ e grupo $2 \geq 6$ atendimentos $(n=15)$.

RESULTADOS: Houve redução da dor oncológica mensurada pelos descritores sensitivo $(p=0,02)$ e misto $(p=0,05)$ do questionário de McGill e na escala visual numérica $(\mathrm{p}=0,03)$ nos pacientes que realizaram no mínimo seis sessóes de fisioterapia. Houve correlação significativa $(\mathrm{r}=0,81 ; \mathrm{p}<0,001)$ entre a redução da dor mensurada pela escala visual numérica e a redução da dor mensurada pelo questionário McGill Total. Não houve diferenças significativas no teste de sentar e levantar e no questionário de capacidade funcional pelo Eastern Cooperative Oncology Group.

CONCLUSÃO: Foram necessárias no mínimo seis sessôes de fisioterapia com ênfase na cinesioterapia para promover redução da dor oncológica em pacientes hospitalizados. Recomenda-se o uso do instrumento multidimensional na avaliação da dor oncológica em pacientes hospitalizados submetidos à fisioterapia.

Descritores: Dor do câncer, Fisioterapia, Mensuração da dor, Neoplasia. 


\section{INTRODUCTION}

According to the World Health Organization (WHO), cancer is a public health problem in developing countries, where it is estimated that in the coming decades it will affect $80 \%$ of individuals with more than 20 million new cases by $2025^{1}$. In oncology, physiotherapy appears as a way to preserve, maintain and restore the functional kinetic integrity of the cancer patient's organs and systems, as well as to prevent disorders caused by the treatment of the disease ${ }^{2}$. In oncology, physiotherapy acts in an integral and interdisciplinary way in health promotion at all levels of care, rescuing the individual's functionality ${ }^{3}$.

Most cancer patients complain of pain, and its control/attenuation is among the priorities of the multiprofessional team ${ }^{2}$. Cancer pain can be located in several anatomical sites and with different causes, being considered a mixed pain ${ }^{4}$. In addition to pain, patients may have a range of motion restriction, sensitivity alteration, muscle weakness, axillary web syndrome, lymphedema, and scarring changes ${ }^{3}$. Physiotherapy can contribute with specific techniques, allowing pain relief and improvement in the quality of life $e^{4}$. A retrospective study reported that the physiotherapy intervention promoted functionality improvements in palliative care patients 5 . Prospective studies are needed to better understand this area of professional practice on cancer pain in a hospital environment ${ }^{5}$. Regular physical exercise can also attenuate pain by reducing endogenous system receptor phosphorylation, increased serotonin levels, and opioid activation in the central nervous system (CNS) inhibitory pathways ${ }^{6}$. However, few studies have assessed the effects of kinesiotherapy on cancer pain in a hospital environment.

Within this context, this study aimed to assess the effects of therapeutic exercises on cancer pain and functional capacity in hospitalized patients.

\section{METHODS}

A quasi-experimental research was performed, with pre and post-intervention assessment, in hospitalized cancer patients. Inclusion criteria were age over 18 years old, diagnosis of cancer by anatomical pathology examination, in-hospital physiotherapy care from March to July 2018. Patients with neurological disease, acute rheumatic disease, unable to walk or to perform the proposed tests requested by the physiotherapist. The sample size calculation was obtained using the $G^{*}$ Power software, using the McGill Pain Questionnaire values. The sample was estimated at 40 individuals, considering a $95 \%$ confidence interval and a significance level of $5 \%$ with an effect size of 0.80 . Data collection was performed at the Sáo Vicente de Paulo Hospital in the city of Passo Fundo/RS.

All subjects were assessed with a semi-structured questionnaire at admission and discharge. The following clinical information was collected: length of stay, type of tumor, history of treatment before chemotherapy (surgical and/or radiotherapy and/ or hormone therapy), intention to treat chemotherapy and/or radiotherapy (curative, neoadjuvant, adjuvant or palliative). In addition, patients were asked about the presence of associated diseases, use of drugs during hospitalization, regular physical activity, and smoking. The nutritional classification was determined by body mass index (BMI), verified by weight and height according to age group, and pre-established cutoff points. In the elderly population ${ }^{7}$, BMI reference values were classified as low weight $\leq 22 \mathrm{~kg} / \mathrm{m}^{2}$, eutrophic $>22 \mathrm{~kg} / \mathrm{m}^{2}$ and $<27 \mathrm{~kg} / \mathrm{m}^{2}$ and overweight $\mathrm{BMI} \geq 27 \mathrm{~kg} / \mathrm{m}^{2}$. In the adult population ${ }^{7}$, the reference values were classified as low weight $<18,5 \mathrm{~kg} / \mathrm{m}^{2}$; eutrophic $\geq 18,5$ and $<25,0 \mathrm{~kg} / \mathrm{m}^{2}$; overweight: $\geq 25$ and $<30,0 \mathrm{~kg} / \mathrm{m}^{2}$; and obesity: $\geq 30 \mathrm{~kg} / \mathrm{m}^{2}$.

For pain assessment, each individual received a verbal numeric scale (VNS) sheet to rate their pain in scores ranging from zero to 10 , according to the intensity of the sensation, being zero when there was no pain and 10 the highest imaginable intensity ${ }^{8}$. The McGill Pain Questionnaire is a multidimensional instrument to measure pain by location, intensity, and its behavior considering the sensitive, affective, evaluative, and mixed dimensions ${ }^{9}$. It has reliability and good validity in cancer patients ${ }^{8,10}$.

The International Physical Activity Questionnaire (IPAQ) considers walking activities, moderate and vigorous physical activity, and has been used in cancer patients ${ }^{10}$. The interpretation of IPAQ was in accordance with the recommendations suggested by the group of scientific reviewers ${ }^{11}$. The sit-to-stand test (STS) from a chair assessed lower limb strength and endurance $^{10}$. At the signal, the participant had to stand up, stand fully, and then return to a sitting position. The participant was encouraged to complete as many repetitions as possible within 30 seconds $^{12}$. Functional capacity was assessed using the Eastern Cooperative Oncology Group (ECOG) scale, a method of global measurement of functional performance ${ }^{13}$ that has been used in cancer patients ${ }^{14,15}$.

In all visits, the physiotherapist performed a detailed anamnesis with functional tests and physical examination; from this, the therapeutic plans were elaborated. The patients performed strength training with halter and elastic band ${ }^{16}$, active and passive muscle stretching, and aerobic exercise through aisle walk or low to moderate intensity cycle ergometer ${ }^{3}$. In cases of thrombocytopenia, the exercises were assisted active or passive mobilization. Respiratory management consisted of ventilatory patterns, pulmonary re-expansion, and bronchial hygiene techniques ${ }^{3}$. On average, the physiotherapy sessions lasted from 20 to $30 \mathrm{~min}$ utes and were performed once a day. Patients were stratified according to the number of sessions performed. Group 1 included those who performed $\leq 5$ sessions and group 2 those who performed $\geq 6$ sessions.

This study was approved by the Research Ethics Committee of the University of Passo Fundo (UPF) under number 2.572.490, respecting the Resolution 466/2012 of the National Health Council. All participants signed the Free and Informed Consent Term (FICT).

\section{Statistical analysis}

Descriptive statistics were performed with mean and standard deviation for quantitative variables and absolute and relative frequencies for categorical variables. The Kolmogorov-Smirnov test was used to analyze the distribution of data. Comparisons 
Table 1. Sample characteristic $(n=40)$

\begin{tabular}{lcc}
\hline Variables & $\mathrm{n}(\%)$ & $\mathrm{p}$-value \\
\hline Age (years old) (mean $\pm \mathrm{SD})$ & $51.9 \pm 18.3$ & \\
Length of stay (days) (mean $\pm \mathrm{SD})$ & $10.3 \pm 7.6$ & \\
Nutritional classification $\left(\mathrm{BMI} \mathrm{kg} / \mathrm{m}^{2}\right)$ & & \\
Low weight & $22(55)$ & $0.001^{*}$ \\
Eutrophic & $15(37.5)$ & \\
Overweight & $2(5)$ & \\
Obesity & $1(2.5)$ & \\
Cancer types & & \\
Solid tumors & $21(52.5)$ & \\
Hematologic tumors & $19(47.5)$ & 0.75 \\
Radiotherapy & & \\
Palliative & $6(15)$ & \\
Healing & $4(10)$ & \\
Adjuvant & $2(5)$ & \\
Did not perform & $28(70)$ & $0.001^{*}$ \\
Chemotherapy & & \\
Palliative & & \\
Adjuvant & $28(70)$ & \\
Healing & $5(12.5)$ & \\
Did not perform & $5(12.5)$ & \\
IPAQ & $2(5)$ & \\
Sedentary & & \\
Irregularly active & & \\
Active & & \\
\hline
\end{tabular}

$\mathrm{IPAQ}=$ International Physical Activity Questionnaire; $\mathrm{SD}=$ standard deviation; $\mathrm{BMI}=$ body mass index; variables expressed as absolute and relative frequency. ${ }^{*}$ Chi-square test $p<0.05$. between pre- and post-intervention values were analyzed by the Wilcoxon test. Categorical variables were analyzed by the Chisquare test. The correlation between the VNS and the McGill questionnaire was performed by the Spearman test after the calculation of the deltas of variation (post-intervention - pre-intervention). Values of $\mathrm{p} \leq 0.05$ were considered significant.

\section{RESULTS}

Forty patients were assessed, most of them male 25 (62.5\%) and with a mean age of $51.93 \pm 18.35$ years old. Solid tumors prevailed in 21 (52.5\%) patients, as described in table 1.

Table 2 shows the assessments of VNS, McGill, ECOG, and the sit-to-stand test pre and post-intervention physiotherapy. In the group with $\geq 6$ physiotherapy sessions, the instruments that assessed pain, VNS and Total McGill, showed a significant decrease in scores $(p=0.04$ and $p=0.03)$ in the post-intervention period, respectively. The Sensitive and Mixed sub-items of the McGill questionnaire showed a significant decrease in scores ( $p=0.02 ; p=0.05)$ in the post-intervention period, respectively. No significant differences were found in the sit-up test and the ECOG functional capacity scale.

Table 3 shows the use of pain-reducing drugs during hospitalization, classified as non-opioids, opioids, and absence of pain drugs. There were no significant differences between groups stratified by the number of physiotherapy sessions. This result suggests that the reduction in pain scores is related to physiotherapy intervention when $\geq 6$ sessions.

There was a significant correlation $(r=0.81 ; \mathrm{p}<0.001)$ between pain reduction measured by VNS and pain reduction measured by the McGill Total questionnaire. Both instruments were able to measure the reduction of cancer pain in patients undergoing physiotherapy.

Table 2. Pain assessments, Eastern Cooperative Oncology Group, and sit-to-stand test pre and post-intervention physiotherapy

\begin{tabular}{|c|c|c|c|c|c|c|}
\hline & \multicolumn{3}{|c|}{$\begin{array}{c}\text { Group } 1(n=25) \\
\leq 5 \text { physiotherapy sessions }\end{array}$} & \multicolumn{3}{|c|}{$\begin{array}{c}\text { Group } 2(n=15) \\
\geq 6 \text { physiotherapy sessions }\end{array}$} \\
\hline & Pre & Post & $\mathrm{p}$-value & Pre & Post & $p$-value \\
\hline VNS & $1.52 \pm 2.8$ & $0.68 \pm 1.5$ & 0.20 & $2.47 \pm 3.1$ & $0.87 \pm 2.5$ & $0.03^{*}$ \\
\hline McGill total & $7.5 \pm 12.6$ & $4.2 \pm 11.2$ & 0.23 & $14.2 \pm 19.4$ & $2.6 \pm 6.7$ & $0.04^{*}$ \\
\hline Affective & $1.2 \pm 2.9$ & $0.68 \pm 1.8$ & 0.17 & $2.6 \pm 4.6$ & $1.06 \pm 3.1$ & 0.23 \\
\hline Evaluative & $0.68 \pm 1.3$ & $0.28 \pm 0.67$ & 0.12 & $1.06 \pm 1.7$ & $0.4 \pm 1.2$ & 0.19 \\
\hline Sensitive & $4.76 \pm 7.9$ & $2.72 \pm 6.4$ & 0.40 & $7 \pm 8.5$ & $0.8 \pm 1.6$ & $0.02^{*}$ \\
\hline Mixed & $1.2 \pm 2.4$ & $0.8 \pm 1.75$ & 0.45 & $3.1 \pm 4.6$ & $0.26 \pm 0.79$ & $0.05^{\star}$ \\
\hline ECOG & $1.3 \pm 0.9$ & $1.4 \pm 0.9$ & 0.14 & $1.6 \pm 0.6$ & $1.4 \pm 0.6$ & 0.4 \\
\hline STS & $11.6 \pm 4.5$ & $10.6 \pm 6.6$ & 0.24 & $10.7 \pm 2.5$ & $10.2 \pm 4$ & 0.61 \\
\hline
\end{tabular}

VNS = verbal numeric scale; STS = 30-second sit-to-stand test; ECOG = Eastern Cooperative Oncology Group. Variables expressed as mean and standard deviation ${ }^{*} \mathrm{p} \leq 0.05$, Wilcoxon test.

Table 3. Pain control drugs prescribed during hospitalization, stratified by the number of physiotherapy sessions

\begin{tabular}{lccc} 
& Group $1(\mathrm{n}=25)$ & Group 2 $(\mathrm{n}=15)$ & $\mathrm{p}$-value* \\
& $\leq 5$ physiotherapy sessions & $\geq 6$ physiotherapy sessions & $13(86.7 \%)$ \\
Non opioids & $18(72 \%)$ & $1(6.7 \%)$ & 0.36 \\
Absence of pain drugs & $6(24 \%)$ & $1(6.7)$ & \\
\hline
\end{tabular}




\section{DISCUSSION}

The results showed that physiotherapy with an emphasis on kinesiotherapy reduced cancer pain in hospitalized patients. The VNS and McGill questionnaire showed decreased pain in patients who had at least six physiotherapy sessions. In addition, a strong association was found between the two pain assessment instruments post-intervention physiotherapy.

Corroborating this study, Rett et al. ${ }^{17}$ reported that kinesiotherapy effectively contributed to the reduction of upper limb pain in a breast cancer patient. These authors showed that pain reduction occurred after the 10th session of physiotherapy ${ }^{17}$. Physiotherapy in palliative care patients can be performed using manual distraction techniques, massage, and relaxation techniques ${ }^{18}$. A study by Reis et al. ${ }^{19}$, consisting of aerobic, resistance, and flexibility exercises, was able to reduce pain intensity in patients undergoing cancer treatment. Studies suggest that physical exercises may modulate the endogenous pain inhibition system ${ }^{6}$. In patients with advanced cancer, analgesia produced by six physiotherapy sessions including massage, mobilization, and kinesiotherapy techniques was reported by López-Sendín et al. ${ }^{20}$, corroborating these results.

Although pain is a subjective and particular sensation of each patient, appropriate methods should be adopted for pain assessment in cancer patients. The McGill's questionnaire assesses pain in the multidimensional form with a general score or in sensitive, affective, evaluative, and mixed dimensions ${ }^{21}$. The McGill provides comprehensive data that can identify the physical, psychological, or behavioral aspects of pain ${ }^{8}$. On the other hand, the VNS is a unidimensional scale that measures pain intensity, widely used due to its rapid comprehension ${ }^{22}$.

In this study, there was a prevalence of physical inactivity, corroborating the results found by Rogers et $\mathrm{al}^{23}$, who assessed the level of physical activity in 483 patients with breast cancer. The present sample presented suboptimal body weight in $55 \%$ of patients, BMI $\leq 22 \mathrm{~kg} / \mathrm{m}^{2}$ in the elderly or $<18.5 \mathrm{~kg} / \mathrm{m}^{2}$ in adults under 60 years old. According to a study that assessed the nutritional status of 96 cancer patients, there was a predominance of malnutrition in this population ${ }^{24}$, corroborating these results. Low weight is usually associated with progressive loss of body mass, functional impairment, and chemotherapy treatment ${ }^{24}$.

Two studies ${ }^{25,26}$ characterized the clinical profiles of cancer patients, demonstrating male prevalence, diagnosis of solid tumors, undergoing treatment with palliative chemotherapy, presenting pain as the most common sign and symptoms, results that corroborate this study.

A randomized clinical trial assessed the effects of aerobic training associated with muscle strengthening in patients with lung cancer undergoing chemotherapy ${ }^{27}$. The authors reported reduced cancer-related fatigue and improved functional independence of activities of daily living, as measured by the Barthel Index, after the supervised exercise program ${ }^{27}$. The studies by Pereira, Santos and Sarges ${ }^{15}$ and Mangia et al. ${ }^{10}$ reported that the functional capacity assessed by the ECOG questionnaire and the STS can contribute to the elaboration of care plans for the oncologic patient care, being that by identifying the functionality, mea- sures are taken to prevent or reduce functional impairment and the risk of complications. However, in this study, no significant changes in functional capacity were observed after the physiotherapy intervention.

\section{CONCLUSION}

The physiotherapy program with a minimum of six sessions and an emphasis on kinesiotherapy promoted the reduction of cancer pain in hospitalized patients. In the McGill questionnaire, the frequency of sensitive and mixed descriptors decreased after the physiotherapy intervention.

\section{REFERENCES}

1. Instituto Nacional do Câncer. Fisioterapia em oncologia (INCA). [Acesso em: 5 de novembro de 2018]. Disponível em:http://www.inca.gov.br/estimativa/2016/estimativa-2016-v11.pdf.

2. Instituto Nacional do Câncer. Fisioterapia em oncologia (INCA). [Acesso em: 5 de novembro de 2018]. Disponível em: http://wwwl.inca.gov.br/conteudo_view.as$\mathrm{p}$ ?ID $=682$.

3. Matheus LBG, Silva LLS, Figueiredo LC. Fisioterapia em oncologia In: Santos M, Corrêa ST, Faria BBDL, Siqueira MSG, Reis DEP, Abreu CKA, et al. (editores). Diretrizes oncológicas. $1^{\text {a }}$ ed. Rio Janeiro: Elsevier; 2017.

4. Raphael J, Ahmedzai S, Hester J, Urch C, Barrie J, Williams J, et al. Cancer pain part 1: pathophysiology; oncological, pharmacological, and psychological treatments: a perspective from the British Pain Society endorsed by the UK Association of Palliative Medicine and the Royal College of General Practitioners. Pain Med. 2010;11(5):742-64.

5. Montagnini M, Lodhi M, Born W. The utilization of physical therapy in palliative care unit. J Palliat Med. 2003;6(1):11-7.

6. Lima VL, Abner TS, Sluka KA. Does exercise increase or decrease pain? Central mechanisms underlying these two phenomena. J Physiol. 2017;595(13):4141-50.

7. Sistema de Vigilância Alimentar e Nutricional do ministério da saúde (SISVAN). Sistema que informa a classificação nutricional conforme o Índice de Massa Corporal (IMC)[Acesso em: 3 de agosto de 2017]. Disponível em:http://tabnet.datasus.gov.br/ cgi-win/SISVAN/CNV/notas_sisvan.html.

8. Barbosa IM, Sales DS, Oliveira LM, Sampaio DV, Milhome AG. Pain in onco-hematologic patients and its association with analgesia. Rev Dor. 2016;17(3):178-82.

9. Pimenta CA, Teixeira MJ. Questionário de dor McGill: proposta de adaptação para a língua portuguesa. Rev Esc Enferm USP. 1996;30(3):473-83.

10. Mangia SA, Coqueiro NLO, Azevedo FC, Araujo HTS, Amorim EO, Alves CNR, et al. What clinical, functional, and psychological factors before treatment are predictors of poor quality of life in cancer patients at the end of chemotherapy? Rev Assoc Med Bras. 2017;63(11):978-87.

11. International Physical Activity Questionnaire IPAQ (2004). Guidelines for Data Processing and Analysis of the International Physical Activity Questionnaire (IPAQ) Short Form. Version 2.0. [Acesso em: 7 maio de novembro de 2018]. Disponível em:<http://www.ipaq.ki.se> Acesso em 07/05/2018.

12. Rikli RE, Jones J. Teste de Aptidão Física para Idosos. Barueri SP: Manole; 2008.

13. Oken MM, Creech RH, Tormey DC, Horton J, Davis TE, McFadden ET, et al. Toxicity and response criteria of the Eastern Cooperative Oncology Group. Am J Clin Oncol. 1982;5(6):649-55.

14. Machado L, Saad IA, Honma HN, Morcillo AM, Zambon L. Evolution of performance status, body mass index, and six-minute walk distance in advanced lung cancer patients undergoing chemotherapy. J Bras Pneumol. 2010;36(5):588-94. English, Portuguese.

15. Pereira EE, Santos NB, Sarges ES. Avaliação da capacidade funcional do paciente oncogeriátrico hospitalizado. Rev Pan-Amaz Saude. 2014;5(4):37-44.

16. Henke CC, Cabri J, Fricke L, Pankow W, Kandilakis G, Feyer PC, et al. Strength and endurance training in the treatment of lung cancer patients in stages IIIA/IIIB/IV. Support Care Cancer. 2014;22(1):95-101.

17. Rett MT, Mesquita PJ, Mendonça AR, Moura DP, DeSantana JM. A cinesioterapia reduz a dor no membro superior de mulheres submetidas à mastectomia ou quadrantectomia. Rev Dor. 2012;13(3):201-7.

18. Barawid E, Covarrubias N, Tribuzio B, Liao S. The benefits of rehabilitation for palliative care patients. Am J Hosp Palliat Med 2015;32(1):34-43.

19. Reis AD, Pereira PT, Diniz RR, de Castro Filha JG, Dos Santos AM, Ramallo BT, et al. Effect of exercise on pain and functional capacity in breast cancer patients. Health Qual Life Outcomes. 2018;16(1):58

20. López-Sendín N, Alburquerque-Sendín F, Cleland JA, Fernández-de-las-Peñas C. Effects of physical therapy on pain and mood in patients with terminal cancer: A pilot randomized clinical trial. J Altern Complement Med. 2012;18(5):480-6.

21. Mendes PM, Avelino FV, Santos AM, Falcâo LM, Dias SR, Soares AH. Aplicação da 
escala de McGill para avaliação da dor em pacientes oncológicos. Rev Enferm UFPE. 2016;10(11):4051-7.

22. Martinez JE, Grassi DC, Marques LG. Analysis of the applicability of different pain questionnaires in three hospital settings: outpatient clinic, ward and emergency unit. Rev Bras Reumatol. 2011;51(4):299-308. English, Portuguese.

23. Rogers LQ, Markwell SJ, Courneya KS, McAuley E, Verhulst S. Physical activity type and intensity among rural breast cancer survivors: patterns and associations with fatigue and depressive symptoms. J Cancer Surviv. 2011;5(1):54-61.

24. Dos Santos CA, Ribeiro AQ, Rosa Cde O, Ribeiro Rde C. [Depression, cognitive deficit and factors associated with malnutrition in elderly people with cancer]. Cienc
Saude Colet. 2015;20(3):751-60.

25. Boaventura AP, Vedovato CA, Santos FF. Perfil dos pacientes oncológicos atendidos em uma unidade de emergência. Cien Enferm. 2015;21(2):51-62.

26. Visentin A, Mantovani MF, Kalinke LP, Boller S, Sarquis LM. Palliative therapy in adults with cancer: a cross-sectional study. Rev Bras Enferm. 2018;71(2):252-8. English, Portuguese.

27. Pyszora A, Budzynski J, Wójcik A, Prokopv A, Krajnik M. Physiotherapy programme reduces fatigue in patients with advanced cancer receiving palliative care: randomized controlled trial. Support Care Cancer. 2017;25(9):2899-908. Erratum in: Support Care Cancer. 2017;25(9):2909. 